Teerawong Laosuwan, Asst. Prof. Department of Physics, Faculty of Science, Mahasarakham University, Maha Sarakham, Thailand, e-mail: teerawong@msu.ac.th

\title{
THE PARTICIPATE TRIPARTITE OF GEOGRAPHIC INFORMATION SCIENCE VIA OPEN SOURCE SOFTWARE EDUCATION
}

\begin{abstract}
Resume
This article describes educational experiences in an advanced graduate GIScience courses together with propose specific tripartite (teachers, researchers, and practitioners) contributions. By combining high-quality interoperable data between past and present monitored time using expert software conjointly developed by tripartite cooperation, new designs and applications with a complex thematic topographic map were successfully developed through an intensive work. Conceptual frameworks and practical topics of the application can be different from student to student depending on metadata, georeferencing, digitizing and topology building, and spatial interpolation and spatial analysis. Former students can work on data they have been introduced into the GIS, taking care of every detail about data, metadata, data models, formats, file relationships, etc. The experience can be easily adapted to other courses in the university over Thailand.
\end{abstract}

Keywords: Participate tripartite, GIS Open source software, Education

\section{Introduction}

It is well known that teaching of the Geographic Information Science (GIScience) (the concept of GIScience illustration in Figure1) benefit very important contributions worldwide [1]. GIScience is the academic theory behind the development, use, and application of Geographic Information Systems (GIS) [2, 3]. It is concerned with people, hardware, software, and geospatial data. GIScience addresses fundamental issues raised by the use of GIS and related information technologies [4]. In Thailand, The GIScience course education are several in the public universities such as Mahasarakham University (undergraduate), Suranaree University of Technology in Master's and $\mathrm{PhD}$ degree. In addition, some of the private Universities in Thailand are currently opened GIS course such as Hatyai University (undergraduate) which curriculum development by Prof. Dr. Paisan 
Laosuwan, Dean, Faculty of Science and Technology, Hatyai University [5]. The GIScience course (undergraduate, master and doctorate degree) in Thailand still provides teaching different and depending on the University is to be determined. There are some specific points in GIScience course that incommode certain course designing from fully defined for several reasons e.g. excessively many academic focused and/or too many practical approaches, insufficient geographical materials (paper maps (i.e. ground water, geomorphology, soil suitability and soil type, etc), satellite datasets, etc), additionally unavailability of needed GIS software (too expensive price).

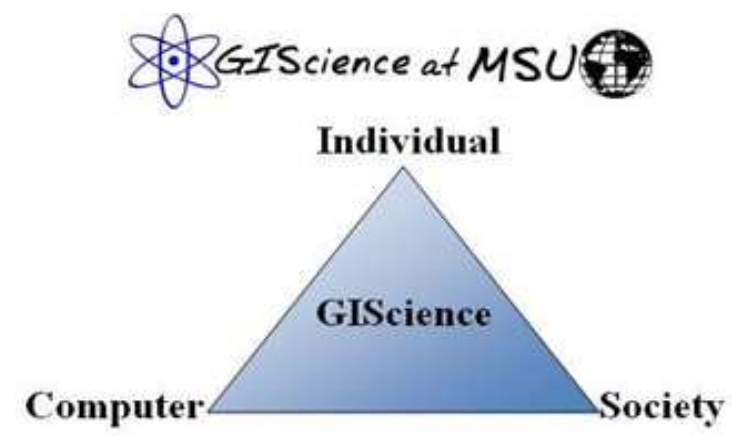

Figure 1 Illustrate GIScience

These are basic necessities that forced us to look for more alternative teaching designs, both theoretical and practical points of view, for the courses. One example is that high-quality metadata availability for the datasets not only make information retrieving from metadata easier (e.g. with obvious derivations depending on whether it is the GIS or RS course), but also improve blunder and other serious errors avoiding. Furthermore, the high-quality metadata can lead to more precise calculations which are not possible without prior metadata completion (e.g., known height units is proceeded to obtain variables derived from digital elevation models) and properly recording the lineage and subsequent processes on a dataset, etc. The primary goal of this article is to illustrate the contributions (which require multiple inputs and long term experience to obtain a successful result) of different GIScience teaching design participants based on the specific courses. All transmitted ideas should be considered as general. They are useful not for applying to similar courses only, but for design other GIScience courses also. Finally, as the entire classroom sessions are computer base developed, the software components are thus important tool to fulfilling the teaching requirements by specific education aspect incorporation.

\section{Instances from the advanced Giscience course}

Firstly, in the department of physics (applied physics), faculty of science, mahasarakham university decision was made in course designing to cover advances level 
GIScience courses with fulfill GIScience cycle such as using free open source software [69], geo-referencing in advanced method [10, 11], spatial interpolation [12, 13] and real time spatial data analysis, giving specialized practices and examples that implied underlying theory in practical ways [14-19]. The GIScience courses (the course about 13 week of each semester not include 1 week for midterm examination and 1 week for final examination) scope covers the following main topics; 1) Geo-referencing and digitizing, 2) Metadata with fully completion, 3) Spatial interpolation and ,4) GIS analysis with application model (mathematical model), 5) Internet GIS service and Web map service systems.

The objective was to analyze data of mapping standard (scale 1:50000 and 1:4000), landuse and landcover details including the percentages of occupied land, forest ages, agricultural usages, bare soil etc, and peripheral information. The student amount is 30 students (undergraduate and graduate) received the map sheet such as landuse/landcover. They would learn how to scan or retrieve the geo-reference and its following rigorous cartographic according to GIS criteria (from the scan procedures and criteria to formats, accuracies, etc), They would also try to understand the value of ancient cartography as a valuable source for understanding land dynamics and the problematic. They could also download updated digital data information from the same area and try to understand their advantages, problems, etc. Complementary exercises dealt with other materials such as nautical charts, ancient orthophotos, etc., provide chances for geographic calculators use (for example, some maps were the Universal Transverse Mercator (UTM) while the coordinates were given at the map corner in longitude- latitude data). This could reinforce the student knowledge in form of projections, reference systems, etc. The geo-reference raster map had to be correctly in metadata form (for example the planimetric accuracy information had to be in Root Mean Square values of the geo-referencing process versus the nominal accuracy of the series they were using). Next, former students would digitize both the categorical landuse/landcover information and the peripheral related data (boundary, height spots, contour lines, road, drainage, etc). During the process, emphasis was laid to multi- field (several attributes were given for each polygon) and the multi-record understanding nature (due to scale, some polygons contain several sets of attributes, and fractional cover indices were also given in the original map) of various categorical parts in the complex map which were digitizing contour lines and drainage, height spots, and polygon limits, polygon multi-attribute and multi-record information entering part, etc. It 
was hard work in obtaining expert digitizing and vector editing abilities as well as building the accurate geographic datasets. Emphasis was also placed in different boundary attributes and polygons themselves (boundaries such as sheet limits, shoreline, etc; in term of area information they were urban areas, rice crops, etc). In case of deliverable geo-reference, a detailed metadata editing was also compulsory for all these vector layers (landuse/landcover limits, landuse/landcover polygons, contour lines, etc). Regarding peripheral related data, it served as a very good interpolation lessons: of points (regularly and irregularly distributes), from contour lines, considering break lines, etc. So they were provided to learn and practice with bilinear and bicubic interpolator methods, inverse distance weighting approaches, splines, contour line interpolation etc. A detailed metadata editing is also compulsory for interpolated outputs. Finally, GIS analysis section made the course complete. This part has two additional improvements which had been declared during the first course. The first one was that students work on data they had introduced into the GIS, taking care of every detail about data, metadata, data models, file relationships and formats etc. This was very valuable point appreciated by the students who realized that the analysis previously done was not the exercises giving the same result as other classmates (or even previous classes). They were really new ones and each student was the first one who discovered this geographic reality. The second one is that, in case of the land use/ land cover map, presences of more than one record per polygon caused needs in adequate proportional area computation and ability to foresee the after-rasterizing consequences, etc. It was important to note that as there were more than 830 topography map sheets (1:50,000 in Thailand) [20] and that each student worked with a quarter, then each one had to deal with unique materials (not only among classmates, but also among yearly courses). These could enrich the existed lessons because they were different cases, nice real examples which could be shown to whole group as a sign of near expert experience.

Almost of students who enrolled our advanced level undergraduate GIScience course were geographers and computer science afterwards, but the course was also attended by other discipline students such as environmental study, Paleontology, geology, etc. Thus, the contents selection in this manner had been taken into account through various complementary examples. In fact, it was attended by students from other disciplines agreed with GIScience course management vision as a transversal key competence across discipline and profession majorities. The expert experience of this advanced GIScience 
course was started in 2002. The development and structure of the lessons was quite similar to the previous versions already designed for theoretical-practical sessions, obligate computer Classroom, 30 learner's maximum per classroom, 30\% of classroom time devoted to tutor-supervising homework, about $40 \%$ devoted time for homework (theory lectures, practical the computer for geo-referencing, digitizing, etc), and continuous evaluations (theoretical and practical) after each part of the course. A final report with complete process done over the 1:50000 quarter sheet together with all digital material generated was the final deliverable requirement to be evaluated.

\section{The contribution of the academic and the practitioner}

The previously design of the second GIScience course benefited from various contributions from several participants, namely:

\subsection{From the very beginning}

Quantitative Geography was interested by several members of the department. GIS and Remote Sensing quickly become important matters. Certainly, Cartography was also specially attended, notably after establishment of a complete Map Library. As you can see, then, these staffs were continually promoted and influenced the availability of teaching resources as well as the curriculum design in which the GIS or Remote Sensing contents were always presented. Two following impacts obviously seen were importance and application of data and metadata models which were continuously increased by time.

\subsection{Open source software}

Open source software developers conducted by the team where teachers, researchers and practitioners vividly exchanged their experiences to provide the integration, original and useful set of tools satisfying the body of knowledge derived from the previous performers. One example is the choice of a module sets that provide, in convenient chain manner, a complete set for working without interruption from primary data to analytical results.

\section{Software analyzing}

To decision for proper teaching aid software, several free GIS software were evaluated according to their functionalities. The desktop GIS software was used for the advanced GIScience courses. The functional assessment of the desktop GIS included the proprietary software. In the Table 1 illustrate software functionally assessment. For the software functions and features point of view, it can be seen from results that the evaluated software, The Quantum GIS can fulfill almost all functional requirements for the advanced 
GIScience courses.

\section{Usage Quantum GIS (QGIS)}

In the past, teaching Geographic information science (GIScience), often designed by using Geographic Information System (GIS) software is proprietary. During the past ten years there has been a collaborative effort to develop and improve the free software called free GIS software by developing in both the desktop and the Internet. Currently, the free GIS software has been used extensively in teaching. From the educational perspective, many current approaches existed in student instructions such as peer response groups [2124] collaborative learning [25-27] and alternative perspectives [28] are all regularly parallel elements of open source approaches. Such open source solutions including their built upon philosophies play the important roles in being metaphors and methods that, provide students practically alternative ways in collaborating and learning.

Table 1 illustrate software functionally assessment

\begin{tabular}{|c|c|c|c|c|c|c|c|c|c|}
\hline Function & 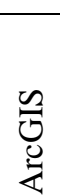 & $\underset{0}{\infty}$ & $\frac{\mathscr{2}}{\sigma}$ & 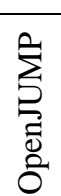 & Function & 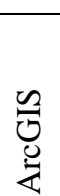 & $\underset{0}{\approx}$ & $\frac{\mathscr{2}}{\sigma}$ & 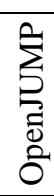 \\
\hline Raster/vector data & $\mathrm{A}$ & A & $\mathbf{A}$ & A & Carto Projections & $\mathrm{A}$ & A & $\mathbf{A}$ & $\mathrm{C}$ \\
\hline Create a map & $\mathrm{A}$ & $\mathrm{A}$ & $\mathbf{A}$ & $\mathrm{C}$ & Vector-to-raster & $\mathrm{A}$ & $\mathrm{A}$ & $\mathbf{F}$ & $\mathrm{E}$ \\
\hline Query attributes & A & $\mathrm{A}$ & $\mathbf{A}$ & $\mathrm{A}$ & Raster resampling & B & $\mathrm{A}$ & $\mathbf{F}$ & $\mathrm{E}$ \\
\hline Query distance & $\mathrm{A}$ & $\mathrm{A}$ & $\mathbf{A}$ & $\mathrm{A}$ & Reclassify & $\mathrm{B}$ & $\mathrm{A}$ & $\mathbf{F}$ & $\mathrm{E}$ \\
\hline Edit attributes & $\mathrm{A}$ & $\mathrm{A}$ & $\mathbf{A}$ & $\mathrm{A}$ & Landscape indices & $\mathrm{C}$ & $\mathrm{A}$ & - & $E$ \\
\hline Table/txt joins & $\mathrm{A}$ & $\mathrm{A}$ & $\mathbf{A}$ & $\mathrm{A}$ & Thiessen polygons & $\mathrm{C}$ & $\mathrm{A}$ & $\mathbf{F}$ & $\mathrm{A}$ \\
\hline Basic statistics & A & $\mathrm{A}$ & $\mathbf{A}$ & $\mathrm{C}$ & Slope & $\mathrm{C}$ & $\mathrm{A}$ & $\mathbf{F}$ & $\mathrm{E}$ \\
\hline Thematic maps & $\mathrm{A}$ & $\mathrm{A}$ & $\mathbf{A}$ & $\mathrm{C}$ & Contouring & $\mathrm{C}$ & $\mathrm{A}$ & $\mathbf{F}$ & $\mathrm{E}$ \\
\hline Polygon overlay & $\mathrm{A}$ & $\mathrm{A}$ & $\mathbf{F}$ & $\mathrm{A}$ & Curvature & $\mathrm{C}$ & $\mathrm{A}$ & $\mathbf{F}$ & $\mathrm{E}$ \\
\hline Zonal statistics & $\mathrm{B}$ & $\mathrm{A}$ & $\mathbf{F}$ & $\mathrm{A}$ & Flow direction & $\mathrm{C}$ & $\mathrm{A}$ & $\mathbf{F}$ & $\mathrm{E}$ \\
\hline Map algebra & B & $\mathrm{A}$ & $\mathbf{F}$ & $\mathrm{E}$ & Flow accumulation & $\mathrm{C}$ & $\mathrm{A}$ & $\mathbf{F}$ & $\mathrm{E}$ \\
\hline Multi-Criteria-Eval & $\mathrm{B}$ & $\mathrm{C}$ & - & $\mathrm{E}$ & Watershed & $\mathrm{C}$ & $\mathrm{A}$ & $\mathbf{F}$ & $\mathrm{E}$ \\
\hline Sliver removal & $\mathrm{B}$ & $\mathrm{A}$ & $\mathbf{F}$ & - & Compound indices & - & $\mathrm{A}$ & $\mathbf{F}$ & $E$ \\
\hline Geom. Union & A & $\mathrm{A}$ & $\mathbf{A}$ & A & Viewshed & $\mathrm{C}$ & A & $\mathbf{F}$ & $\mathrm{E}$ \\
\hline Geom. QA/cleaning & $\mathrm{A}$ & $\mathrm{A}$ & $\mathbf{A}$ & $\mathrm{A}$ & Hillshade & $\mathrm{C}$ & $\mathrm{A}$ & $\mathbf{F}$ & $\mathrm{E}$ \\
\hline IDW & B & A & $\mathbf{A}$ & $\mathrm{E}$ & Profile graph & $\mathrm{C}$ & A & - & $\mathrm{E}$ \\
\hline Spline & $\mathrm{B}$ & $\mathrm{A}$ & $\mathbf{F}$ & - & Extract raster & $\mathrm{C}$ & A & $\mathbf{F}$ & $\mathrm{E}$ \\
\hline Contours to DEM & $\mathrm{B}$ & $\mathrm{A}$ & $\mathbf{F}$ & - & Fuzzy sets & $\mathrm{B}$ & $\mathrm{C}$ & - & $\mathrm{E}$ \\
\hline Kriging & $\mathrm{B}$ & $\mathrm{D}$ & - & $\mathrm{E}$ & Change matrix & - & $\mathrm{A}$ & $\mathbf{F}$ & - \\
\hline Geo-referencing & A & A & $\mathbf{A}$ & $\mathrm{E}$ & SQL & $\mathrm{A}$ & A & $\mathbf{A}$ & A \\
\hline Metadata editing & A & - & - & - & Scripting/Modeller & A & A & $\mathbf{A}$ & A \\
\hline
\end{tabular}

$\mathrm{A}=$ Functionality provided, $\mathrm{B}=$ functionality provided with ArcGIS not with ArcView, $\mathrm{C}=$ Separate plug in/extension, $\mathrm{D}=$ GRASS, E: OpenJUMP, $\mathrm{F}=$ QGIS

The Quantum GIS (QGIS) is free open source Geographic Information System (GIS) and Remote Sensing software. It allows visualization, query, edition, and analysis of raster (remote sensing images, orthophotos, digital terrain models, conventional thematic maps 
with raster structure, etc), vector (topographic and thematic maps that contain points, lines or polygons), and WMS layers (see concept of WMS in Figure 2) [29].

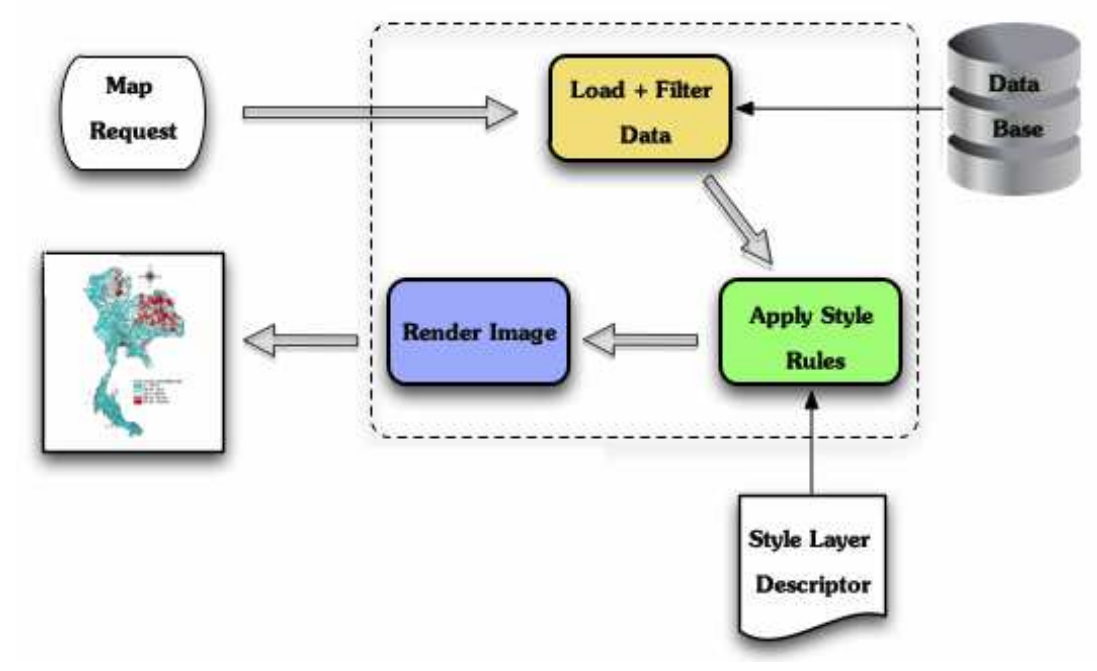

Figure 2 Web map service systems

QGIS was born in May of 2002 and was established as a project on Source Forge in June of the same year. QGIS aims to be an easy-to-use GIS, providing common functions and features. The initial goal was to provide a GIS data viewer. QGIS has reached the point in its evolution where it is being used by many for their daily GIS data viewing needs. QGIS supports a number of raster and vector data formats, with new format support easily added using the plug-in architecture see in Figure 3.

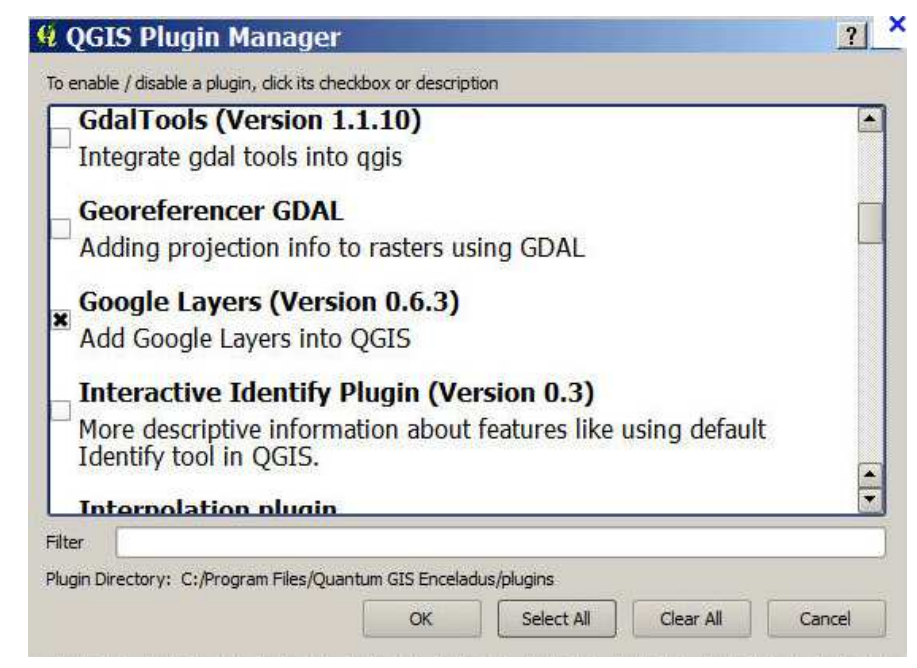

Figure 3 Illustrate QGIS Plug-in

Obviously, there are gradually introduction of the internet usages into the class. Today students access it for metadata querying, data visualization and downloading (when possible and available) the updated digital information from the same area; by this way, 
they understand advantages, problems, etc of the interoperable internet sources and acquire necessary critical visions about the capabilities of this new world that benefit their future expert work. In this sense, the myriad available information on the internet gives much possibility to transform the teacher into a coach [30]. With acknowledging this vast world opportunities and materials, our vision is directed to the role for "teacher as teacher" which can be said in alternative way as "one hour that the students engages with a lecturer is often more valuable than the same hour browsing webpage themselves.

\section{Development of Web GIS and MIS biodiversity database in Phupan forest}

We was used experience in participate tripartite for applied and development of GIS and MIS biodiversity at the local level, which will be accessible to end users through internet backbone (see in Figure 4). The research has paid attention to open source software system instead of costly closed source software [31-33]. GIS databases system has been prepared using Quantum GIS. The MIS database system researcher has decided to use PHP, phpMyAdmin and MySQL (see in Figure 5 and Figure 6). The research outputs have clearly displayed the relationship between the two database systems running over the high speed internet backbone. It is will be used as a foundation for database system in other fields in the future.

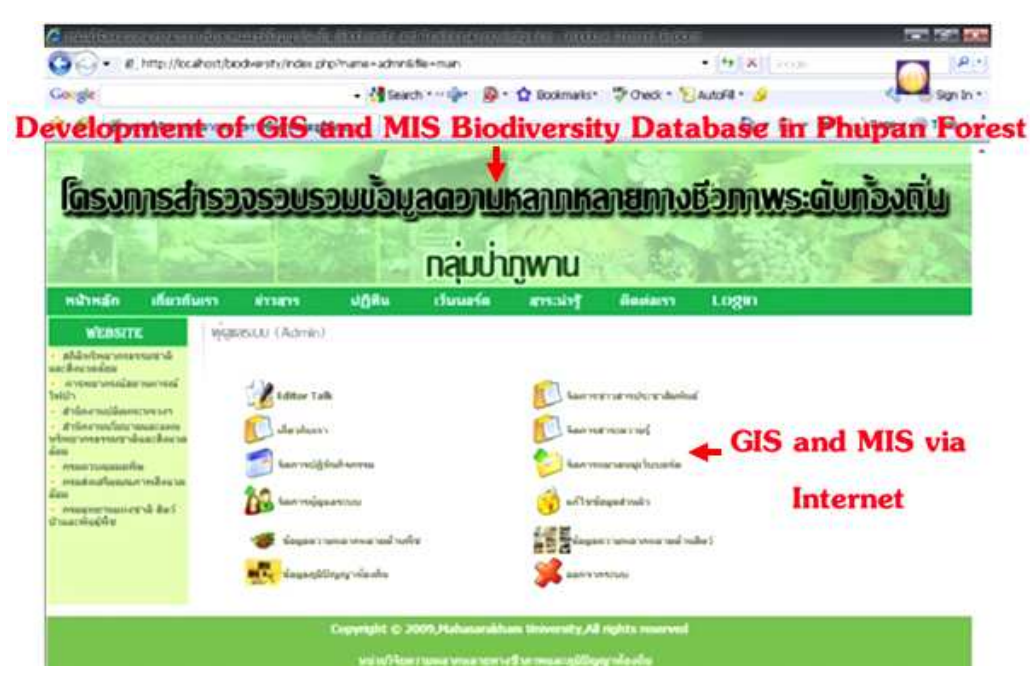

Figure 4 GIS and MIS Biodiversity database 


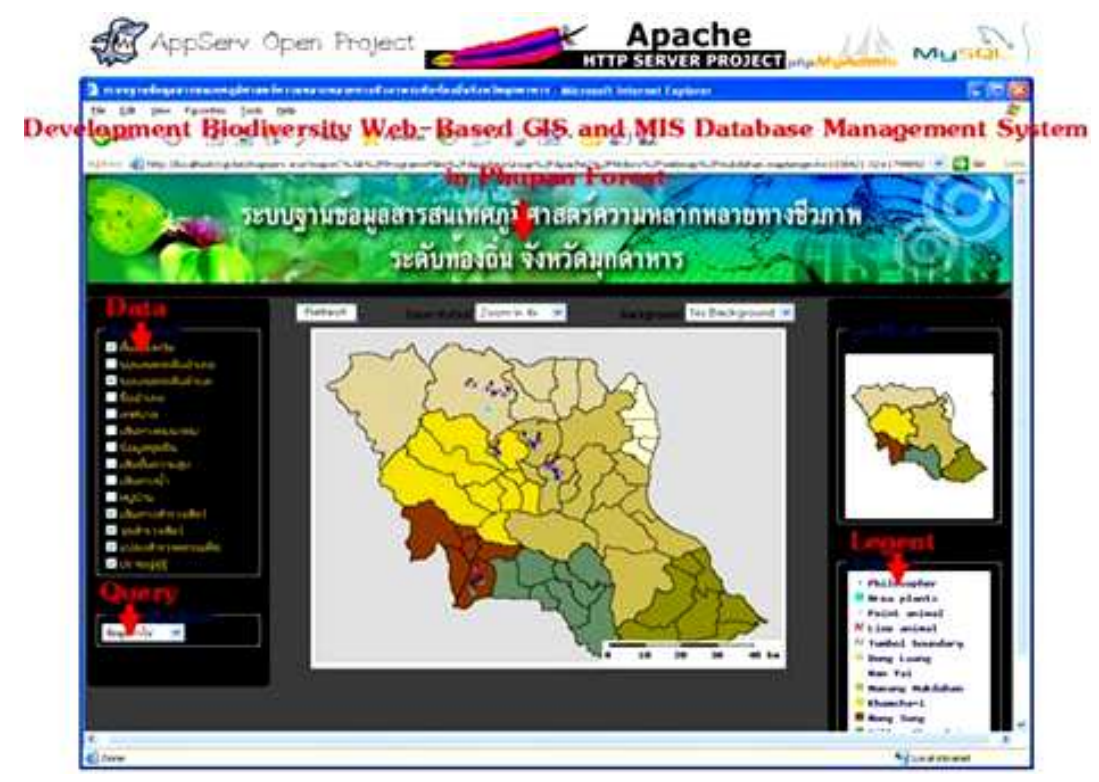

Figure 5 Illustrate of spatial data base online via internet

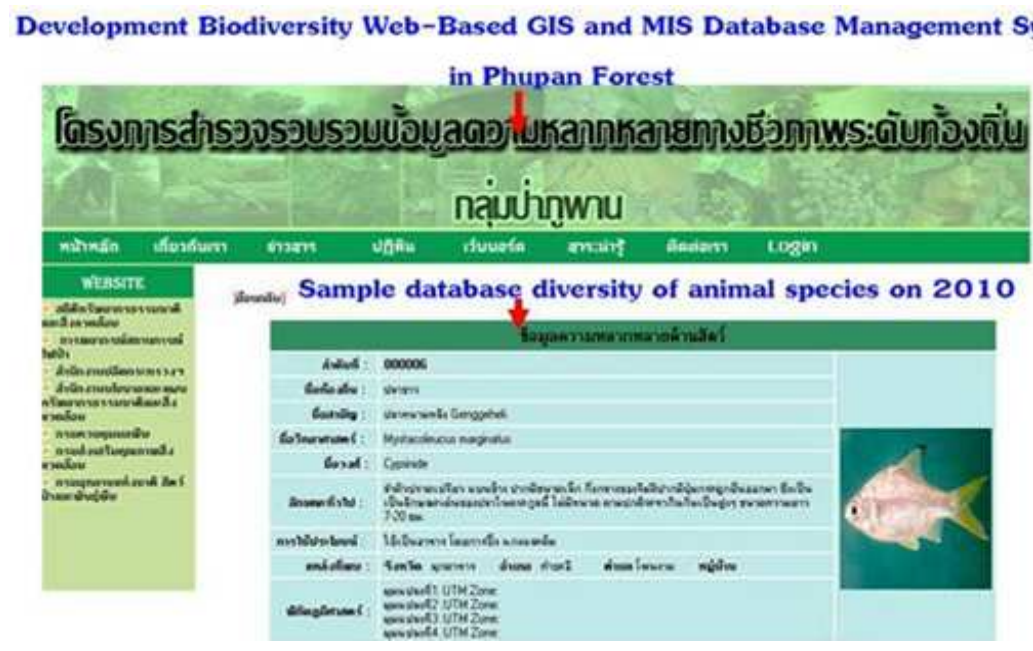

Figure 6 Attribute data base online via internet

\section{Conclusion}

With respect to the use of free open source GIS in teaching, it is believed that free software have achieved a level of maturity that enables them to replace proprietary desktop GIS software in GIScience level courses teaching. The reviewed software appears to be stable and reliable. Combining high quality-interoperable data with free open source GIS developed from the tripartite contributions (teachers, researchers and practitioners) has provided successful educational experience in the advanced GIScience course. One of the most advantages was that students could easier work on data they had introduced in the GIS, taking care of every detail about data, metadata, data models, file relationships and formats etc. Next important point was that it consequently made public digital GIS forms available in certain sheets for the first time. Working on real useful data allows students to perform 
their tasks with unique and valuable process, deal with real "practitioner" data problems occurred during creating or entering new information to the analysis. It also allows teachers to realize and adapt their curricular material with new or alternative incidences. This experience can be easily adapted to other related courses with similar data structures existed in other countries. In addition to the ease availability and accessibility of the software, the GIScience course contents have also been extensively checked in time by hundreds of students and even able to adapt to higher education course in Thailand.

\section{Reference}

1. Gomasathit, T., Laosuwan, T., Chunpang, P., and Uraichuen, Y., (2011). 'Real Experience in GIScience Teaching Aid using GIS Open-Source Software'. International Journal of Geoinformatics 7 (4): 63-67.

2. Goodchild, Michael F., Spatial information science, Proceedings, (1990). Fourth International Symposium on Spatial Data Handling (Zurich, Switzerland, 3-12.

3. Goodchild, Michael F, (1992). Geographical information science, International Journal of Geographical Information Systems 6 (1): 31-45.

4. Wilson, J.P.; Fotheringham, A.S., (2007). The Handbook of Geographic Information Science, Malden, MA: Blackwell Publishing, pp. 3-12.

5. Paisan Laosuwan. Bachelor of Science Program in Geo-informatics (curriculum). Online Available: http://www.hu.ac.th/admissiononline/gis/02.html (05 October. 2008).

6. Royal Thai Survey Department. Online Available: http://www.rtsd.mi.th/index.php. (2011).

7. Grohmann, C., (2004). Morphometric Analysis in Geographic Information Systems: Applications of Free Software GRASS and R, Computers \& Geosciences, 30, 1055-1067.

8. Jolma, A., Ames, D. P., and Horning, N., (2008). Free and Open Source Geospatial Tools for Environmental Modelling and Management. In: Jakeman AJ, Voinov AA, Rizzoli AE and Serena HC (eds), Environmental Modelling, Software and Decision Support. Elsevier, Amsterdam, NL, 163-180. 
9. Steiniger, S., and Bocher, E., (2009). An Overview on Current Free and Open Source Desktop GIS Developments. International Journal of Geographical Information Science, 23(10):1345-1370.

10. Steiniger, S., and Hay, G. J., (2009), Free and Open Source Geographic Information Tools for Landscape Ecology. Ecological Informatics, 4(4):183-195.

11. Moritz, T. (1999). Geo-referencing the Natural and Cultural World, Past and Present: Towards Building a Distributed, Peer-Reviewed Gazetteer System. Presented at the Digital Gazetteer Information Exchange Workshop, Oct 13-14, 1999. Transcribed and edited from audiotape. Available: http://www.alexandria.ucsb.edu/ lhill/dgie/ DGIEwebsite/ session1/ moritz.htm [08 October. 2009].

12. Beaman, R.S. and Conn, B.J. (2003). Automated geoparsing and georeferencing of Malesian collection locality data. Telopea 10(1): 43-52.

13. Moritz, T. Geo-referencing the Natural and Cultural World, Past and Present: Towards Building a Distributed, Peer-Reviewed Gazetteer System. Presented at the Digital Gazetteer Information Exchange Workshop, Oct 13-14, 1999. Transcribed and edited from audiotape. http://www.alexandria.ucsb.edu/ lhill/dgie/DGIE_website/ session1/ moritz.htm [Accessed 02 October. 2009].

14. FGDC. Proposal for Geospatial Positioning Accuracy Standards, Part 3: National Standard for Spatial Data Accuracy. Washington, DC: Federal Geographic Data Committee. http://www.fgdc.gov/standards/projects/FGDC-tndardsprojects / accuracy/part3/progpas3, [08 October. 2009]. (2005a).

15.FGDC. Proposal for Geospatial Positioning Accuracy Standards. Washington, DC: Federal Geographic Data Committee. http://www.fgdc. Gov/standards/projects/FGDCstandards-projects/ accuracy/ part1/progpas1> [02 October. 2009]. (2005b).

16. Hansen, H., and Niedomysl T., (2009). Migration of the creative class: Evidence from Sweden. Journal of Economic Geography, 9(2):191-206.

17. Florida, R.; Mellander, C.; and Stolarick, K. (2008). Inside the black box of regional development: Human capital, the creative class and tolerance. Journal of Economic Geography, 8(5):615-649. 
18. Fritsch, M. (2007). The geography and the effect of creative people in Germany. Jena Economic Research Papers 001-2007, Max Planck Institute of Economics, Iena. McGranahan, D., and Wojan T., Recasting the creative class to examine growth processes in rural and urban counties. Regional Studies, 41(2):197-216.

19. Suire, R. (2006). Creative cluster and relational proximity. Canadian Journal of Regional Science, 28:124-38.

20. Haining R., (1990). Spatial data analysis in the social and environmental sciences. Cambridge University Press, Cambridge, 409p.

21.Strobl, J., Geospatial Competence as Cross-Disciplinary Qualification. Vision paper EUGISES 2010.

22. Walvoord, B. F., (1986), Helping Students Write Well: A Guide for Teachers in all Disciplines, (2 ed.), Modern Language Association, New York.

23. Ginott, H. G., (1993), Teacher and Child: A Book for Parents and Teachers. ${ }^{1}$ st Collier Books ed. New York: Colliers.

24. Freiberg, H. J., (1996), From Tourists to Citizens in the Classroom, in Educational Leadership, Vol. 54, No. 1, 32-36.

25. Davis, B. G., (2001). Tools for Teaching. Jossey-Bass, New York.

26. Hart, S. N., (2005), Eliminating Corporal Punishment: The Way Forward to Constructive Child Discipline. Paris: UNESCO Publishing.

27. Education and Inspections Act, Available: http://www.legislation.gov.uk/ukpga/2006/40/contents. [08 February. 2010].

28. Grasha, T., (1990). The Naturalist Approach to Learning Styles. College Teaching, 38(3):106-113.

29. Opengeospatial, (2012). Online Available: http://www.open geospatial. Org/standards/wms.

30. De Bakker, M., Toppen, F., Changes in the geospatial education landscape. Vision paper EUGISES 2010. [08 February. 2011].

31. Laosuwan, T., Uttaruk, P., Klinhom U., Butthep, C., Samek J. H., Skole, D, L., (2011). Development of Web-GIS Application for Carbon Sequestration in Thailand. International Journal of Geoinformatics, 7 (2): 41-47.

32. Teerawong Laosuwan, (2012), A Web-based GIS development for Natural Resource and Environment, Journal of Applied Technology in Environmental 
Sanitation, 2 (2): 103-108.

33. Teerawong Laosuwan, Supachai Ritjareonwattu, (2012). An Innovative Approach to the Development of Spatial Data Infrastructures and Web 2.0 Technologies, International Journal of Geoinformatics, 8 (2): 53-61.

\section{ПОТРІЙНА УЧАСТЬ В ГЕОГРАФІЧНІЙ ІНФОРМАЦІЙНІЙ НАУЦІ ЧЕРЕЗ ОСВІТУ ВІДКРИТОГО ПРОГРАМНОГО ЗАБЕЗПЕЧЕННЯ}

Тіравонг Лаосуван, помічник професора, відділення фізики, Науковий факультет, Університет Махасаракхам, Маха Саракхам, Таїланд, e-mail: teerawong @msu.ac.th

\section{Анотація}

Ця стаття описує освітній досвід 3 проведення курсів удосконалення 3 Геоінформатичної науки (ГІН), в яких ураховується особливий вклад трьох учасників - викладачів, дослідників і практикуючих фахівців. Об'єднуючи високоякісні міждіючі дані моніторингу, які були отримані у різні періоди часу, використовуючи експертне програмне забезпечення, яке було розроблено і удосконалювалося завдяки спільній, успішній, потрійній, інтенсивній співпраці, були створені нові дизайни і додатки разом $з$ тематичною топографічною картою. Концептуальні структури i практичні теми додатків можуть відрізнятися залежно від студента, метаданих, геопосилань, оцифрування і створення топології, а також від просторової інтерполяції і просторового аналізу. Колишні студенти також можуть працювати з даними, які вони представили в ГІН, беручи до уаги кожну деталь, дані, метадані, моделі даних, формати, файли і т.п. Такий досвід можна легко пристосувати до інших курсів в університетах Таїланду.

Ключові слова: потрійна участь, відкрите програмне забезпечення ГІН, освіта.

\section{ТРОЙСТВЕННОЕ УЧАСТИЕ В ГЕОГРАФИЧЕСКОЙ ИНФОРМАЦИОННОЙ НАУКЕ ЧЕРЕЗ ОБРАЗОВАНИЕ ОТКРЫТОГО ПРОГРАММНОГО ОБЕСПЕЧЕНИЯ}

Тиравунг Лаосуван, помощник профессора, отделение физики, Научный факультет, Университет Махасаракхам, Маха Саракхам, e-mail: teerawong@msu.ac.th 


\begin{abstract}
Аннотация
Эта статья описывает опыт в системе образования по проведению курсов усовершенствования по Геоинформационной науке (ГИН), в которых учитывается вклад трех участников - преподавателей, исследователей и практикующих специалистов. Объединяя высококачественные междействующие данные мониторинга, полученные в разные периоды времени, используя опытное программное обеспечение, разработанное и развиваемое благодаря совместному, успешному тройственному сотрудничеству были созданы новые дизайны и приложения вместе с тематической топографической картой. Концептуальные структуры и практические темы приложения могут отличаться в зависимости от студента, метаданных, гео-ссылок, преобразования в цифровую форму, построения топологии, а также от пространственной интерполяции и пространственного анализа. Бывшие студенты также могут работать с данными, которые они представили в ГИН, учитывая каждую деталь, данные, метаданные, модели данных, форматы, файлы и т.п. Такой опыт может быть легко адаптирован к другим курсам в университетах Таиланда.
\end{abstract}

Ключевые слова: тройственное участие, открытое программное обеспечение ГИН, образование. 